\title{
Characterization of oxidation of glutathione by cytochrome $c$
}

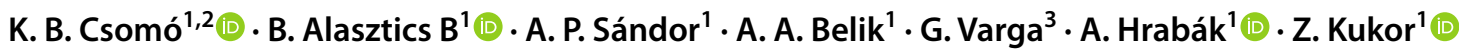

Received: 9 June 2021 / Accepted: 22 October 2021 / Published online: 10 December 2021

(c) The Author(s) 2021

\begin{abstract}
Cytochrome $\mathrm{c}$ is a member of the respiratory chain of the mitochondria. Non-membrane-bound (free) cytochrome c can be reduced by gluthatione as well as ascorbic acid. We investigated the effect of $\mathrm{pH}, \mathrm{Ca}^{2+}, \mathrm{Mg}^{2+}$ and anionic phospholipids on the reduction of cytochrome $\mathrm{c}$ by glutathione.The reduction of cytochrome $\mathrm{c}$ by thiols was measured using photometry. Mitochondrial oxygen consumption was detected by use of oxygen electrode. Glutathione does not reduce cytochrome c at $\mathrm{pH}=7.0$ in the absence of $\mathrm{Ca}^{2+}$ and $\mathrm{Mg}^{2+}$. The reduction of cytochrome $\mathrm{c}$ by glutathione is inhibited by anionic lipids, especially cardiolipin. The typical conditions of apoptosis_elevated $\mathrm{pH}, \mathrm{Ca}^{2+}$ level and $\mathrm{Mg}^{2+}$-increases the reduction of cytochrome c. Glutathione $(5 \mathrm{mM})$ causes increased mitochondrial $\mathrm{O}_{2}$ consumption at $\mathrm{pH}=8.0$, in the presence of ADP either $1 \mathrm{mM} \mathrm{Mg}^{2+}$ or $1 \mathrm{mM} \mathrm{Ca}^{2+}$. Our results suggest that membrane bound cyt $\mathrm{c}$ does not oxidize glutathione. Free (not membrane bound) cytochrome $\mathrm{c}$ can oxidize glutathione. In mitochondria, $\mathrm{O}_{2}$ is depleted only in the presence of ADP, so the $\mathrm{O}_{2}$ depletion observed in the presence of glutathione can be related to the respiratory chain. Decreased glutathione levels play a role in apoptosis. Therefore, membrane unbound cyt c can contribute to apoptosis by oxidation of glutathione.
\end{abstract}

Keywords Cytochrome c $\cdot$ Glutathione $\cdot$ Mitochondria

Data will be made available on reasonable request

Z. Kukor

kukor.zoltan@med.semmelweis-univ.hu

K. B. Csomó

foncsorozas@gmail.com

B. Alasztics B

dr.alasztics@gmail.com

A. P. Sándor

sandoragnes@gmail.com

A. A. Belik

andrea.belik@gmail.com

G. Varga

varga.gabor@dent.semmelweis-univ.hu

A. Hrabák

hrabak.andras@med.semmelweis-univ.hu

1 Department of Biochemistry and Molecular Biology, Institute of Molecular Biology, Semmelweis University, Túzoltó u. 37-47, Budapest 1093, Hungary

2 Department of Conservative Dentistry, Semmelweis University, Szentkirályi u. 47, Budapest 1088, Hungary

3 Department of Oral Biology, Semmelweis University, Nagyvárad tér 4, Budapest 1089, Hungary

\author{
Abbreviations \\ Cyt c Cytochrome c \\ DTT Dithiothreitol \\ EDTA Ethylenediamine tetraacetic acid \\ GSH Glutathione \\ GSSG Oxidized glutathione \\ PTP Permeability transition pore
}

\section{Introduction}

In healthy cells, the primary function of mitochondria is ATP production by the respiratory chain. Cytochrome c (cyt c) is a member of the respiratory chain proteins, and it is located between complex III and complex IV in the intermembrane space of the mitochondrion. In vivo, electrons go to complex III from NADH or from succinate and fatty acids.

The primary function of cyt $\mathrm{c}$ is electron shuttling in the oxidative phosphorylation process.

In physiological conditions cyt $\mathrm{c}$ is bound to the inner mitochondrial membrane. At physiologic $\mathrm{pH}$, cyt $\mathrm{c}$ is a positively charged protein; thus it mainly binds to anionic lipids such as phosphatidyl-serine or mitochondric-specific cardiolipin through electrostatic and hydrophobic interactions 
(Ott et al. 2002). Cyt $\mathrm{c}$ has an important role in the terminal oxidation process, as well as in the electron transport. The unbound part of cyt $\mathrm{c}$ diffuses primarily in the intermembrane space of intact mitochondria at physiological ionic strength (Cortese et al. 1995). Thus in agreement with its role as a soluble, three-dimensional diffusant in the intermembrane space of mitochondria, the cyt c carries electrons from the membrane-bound Complex III to cyt c oxidase (Cortese et al. 1995; Gupte and Hackenbrock 1988).

However, under pro-apoptotic conditions, including oxidative stress, cyt $\mathrm{c}$ translocates into the cytosol to engage in the intrinsic apoptotic pathway, and enters the nucleus where it impedes nucleosome assembly. Other reported functions include cytosolic redox sensing and involvement in the mitochondrial oxidative folding machinery (Alvarez-Paggi et al. 2017).

Cyt c can be released from the intermembrane space. The release of cyt $\mathrm{c}$ from the mitochondria is a key step in the mitochondrion-derived apoptosis. The first step of the release of cyt $\mathrm{c}$ is termination of the bond between cyt $\mathrm{c}$ and cardiolipin. Oxidation of cardiolipin is necessary in order to rupture the bond with the tightly bound cytochrome $\mathrm{c}$. Cyt $\mathrm{c}$ leaves the intramitochondrial space through the permeability transition pore (PTP), but the mechanism of this step is not entirely clear.

In vitro, cyt $\mathrm{c}$ is reduced by miscellaneous reduction agents such as dithiothreitol, glutathione (GSH) or ascorbic acid (Williams and Yandell 1985).

GSH is an important antioxidant; the concentration levels in mammalian cells are in the millimolar range $(1-10 \mathrm{mM})$. The synthesis of GSH from its constituent amino acids occurs exclusively in cytosol. GSH can cross the outer mitochondrial membrane. GSH concentration of mitochondrial intermembrane space is similar to that found in the cytosol (depending on the tissue type). Its transport into the mitochondrial matrix cannot be explained by simple diffusion. Therefore, matrix GSH arises from the cytosol GSH by the activity of specific carriers (Ribas et al. 2014). The GSH levels in the mitochondrion is similar to the GSH levels in the cytosol (Pastore et al. 2003), though mitochondrial GSH concentration is higher than cytosolic (Wahlländer et al. 1979). In the intracellular environment GSH is primarily reduced, the rate of GSH:GSSG is 300-30:1, except in the endoplasmic reticulum, where the ratio is $3-1: 1$. In cardiomyocytes, the intermediate GSH:GSSG ratios may cause reversible mitochondrial $\Delta \Psi \mathrm{m}$, while strongly decreased ratios can cause irreversible PTP activation (Aon et al. 2007).

Cyt $\mathrm{c}$ is found in the mitochondria bound to the inner membrane as well as in the intermembrane space. Due to the oxidizing effect of GSH and ascorbic acid, does it arise whether these reactions can take place in the mitochondria? Can the reduction of cyt c (oxidation of glutathione) be related to free (solved) or membrane-bound cyt c? Our main goal was to study the chemical reaction. The intermembrane space was modeled with free cyt $\mathrm{c}$, while membrane-bound cytochrome $\mathrm{c}$ was modeled with phospholipids. Using rat liver mitochondria, we investigated whether mitochondrial oxygen consumption could change in the presence of GSH.

\section{Materials and methods}

Cyt c reduction The reduction of cytochrome $\mathrm{c}$ was determined by absorbance at $550 \mathrm{~nm}(\varepsilon=21,0001 / \mathrm{mol})$. The typical incubation mixture is composed of $100 \mu \mathrm{M}$ bovine cytochrome c; $40 \mathrm{mM}$ Tris/HCl $(\mathrm{pH} 8.0 ; 7.4$ or 7.0) or $\mathrm{NaHCO}_{3}$ (pH 6.0 and 6.5); $1 \mathrm{mM} \mathrm{GSH} ; \mathrm{CaCl}_{2}, \mathrm{MgCl}_{2}$, concentration was as indicated. The micromolar calcium concentration was regulated by the Ca-EDTA complex (Bártfai 1979).

Preparation of mitochondria Mitochondria were prepared from 180-200 g Wistar rat liver using a standard protocol from Clayton and Shadel (Clayton and Shadel 2012). Animal experiments were performed in accordance with the Guidelines for Animal Experiments of Semmelweis University. A modified biuret method was used to determine mitochondrial protein concentration (Bradford 1976).

Mitochondrial oxygen consumption assay Respiratory rates were determined by measuring the oxygen consumption of mitochondria using Clark type electrode in $1 \mathrm{ml}$ sealed chamber, which was stirred at $37^{\circ} \mathrm{C}$. The mitochondria ( $1 \mathrm{mg}$ protein $/ \mathrm{ml}$ ) were incubated in $250 \mathrm{mM}$ sucrose, $40 \mathrm{mM}$ Tris/ $\mathrm{HCl}(\mathrm{pH} 8.0, \mathrm{pH} 7.4$ and $\mathrm{pH} 7.0)$ or $40 \mathrm{mM}$ $\mathrm{NaHCO}_{3}$ (pH 6.2, 6.5); $5 \mathrm{mM}$ glutathione. $\mathrm{MgCl}_{2}, \mathrm{CaCl}_{2}$, EDTA, ADP concentrations were as indicated.

Data analysis Testing for statistically significant differences $(p<0.05)$ was performed by analysis of variance (ANOVA). Data are given as mean \pm SD for three-six separate experiments. Authors can confirm that all relevant data are included in the article and data will be made available on reasonable request.

Materials Phosphatidyl-serine, phosphatidyl acid, horse Cytochrome c, glutathione, cardiolipin were from SigmaAldrich Kft. (Budapest, Hungary). Other chemicals were from Reanal (Budapest, Hungary).

\section{Results}

Free (without added phospholipids) cyt c was model of cyt $\mathrm{c}$ in the intermembrane space and cyt $\mathrm{c}+$ phospholipids was model of intermembrane bound cyt $\mathrm{c}$. We tested whether 
glutathione could increase mitochondrial $\mathrm{O}_{2}$ intake, so could glutathione act as a respiratory substrate?

\section{Free (model of intermembrane space) cyt c}

\section{Cyt $\mathrm{c}$ reduction by glutathione depends on $\mathrm{pH}, \mathrm{Ca}^{2+}$ and $\mathrm{Mg}^{2+}$ concentration}

In agreement with previous observations (Hancock et al. 2001), glutathione reduces free cyt $\mathrm{c}$. The reduction rate is dependent on $\mathrm{pH}$ and $\mathrm{Ca}^{2+}$ concentration. At $\mathrm{pH}$ 6.2, 6.5 and 7.0 in $1 \mathrm{mM}$ EDTA cyt $\mathrm{c}$ reduction is lightly increases within $300 \mathrm{~s}$ at $25^{\circ} \mathrm{C}$. At elevated pH levels, cytochrome c is reduced by GSH. The rate of reduction of cytochrome $\mathrm{c}$ by GSH notably grows above pH 7.0 (Fig. 1A and B).

$\mathrm{Ca}^{2+}$ has been known to regulate the respiratory chain attached enzymes (pyruvate dehydrogenase, $\alpha$-ketoglutarate dehydrogenase, isocitrate dehydrogenase, ATP synthase, adenine nucleotide translocase etc.) to control cell death (Giacomello et al. 2007; Brookes et al. 2004). The increase in $\mathrm{Ca}^{2+}$ level in the mitochondria is key to cytochrome $\mathrm{c}$ release and apoptosis. Rate of reduction of cytochrome $\mathrm{c}$ dependents on $\mathrm{Ca}^{2+}$ concentration. The maximal reduction rate is measured at $1-4 \mathrm{mM} \mathrm{Ca}^{2+}$, while $10 \mathrm{mM} \mathrm{Ca}^{2+}$ decreased (not significant) the reduction rate (Fig. 2).

$\mathrm{Mg}^{2+}$, as a bivalent cation can modify the reduction of cytochrome $\mathrm{c}$. The reduction of cytochrome $\mathrm{c}$ dependents on $\mathrm{Mg}^{2+}$ concentration. The maximal reduction rate is measured at $10 \mathrm{mM} \mathrm{Mg}^{2+}$ at $\mathrm{pH}=8.0$ (Fig. 3).

\section{The effect of $\mathrm{NaCl}$ on reduction of cytochrome $\mathrm{c}$}

The effect of the bivalent cations can also be due to the ionic strength, so we examined whether $\mathrm{NaCl}$, in a concentration (1.5 mM) equivalent to the ionic strength of $1 \mathrm{mM} \mathrm{CaCl}_{2}$ and $\mathrm{MgCl}_{2}$ concentrations, would affect cyt $\mathrm{c}$ reduction. The ionic strength of $\mathrm{NaCl}$, in a concentration equivalent to the ionic strength of $\mathrm{MgCl}_{2}$ and $\mathrm{CaCl}_{2}$, did not affect the reduction of cyt by GSH (Figure does not show it). The effect was independent of $\mathrm{pH}$.

\section{The effect of thiols (GSH, Cys, DTT) on the reduction of cytochrome $c$}

GSH is the thiol compound of largest concentration in the cells. We investigated if cysteine and dithiothreitol
Fig. 1 Cyt $\mathrm{c}$ reduction by GSH at differently pH. $100 \mu \mathrm{M}$ bovine cytochrome c, $1 \mathrm{mM}$ $\mathrm{GSH}, 1 \mathrm{mM}$ EDTA at $25^{\circ} \mathrm{C}$. A $\mathrm{pH}=7.0,7.4$ and $8.0(40 \mathrm{mM}$ Tris/ $/ \mathrm{HCl})$. B pH=6.0, 6.5 $\left(40 \mathrm{mM} \mathrm{NaHCO}_{3}\right)$ and 7.0 (40 mM Tris/HCl). The reaction was started by adding cytochrome c $(n=6 \pm S D)$
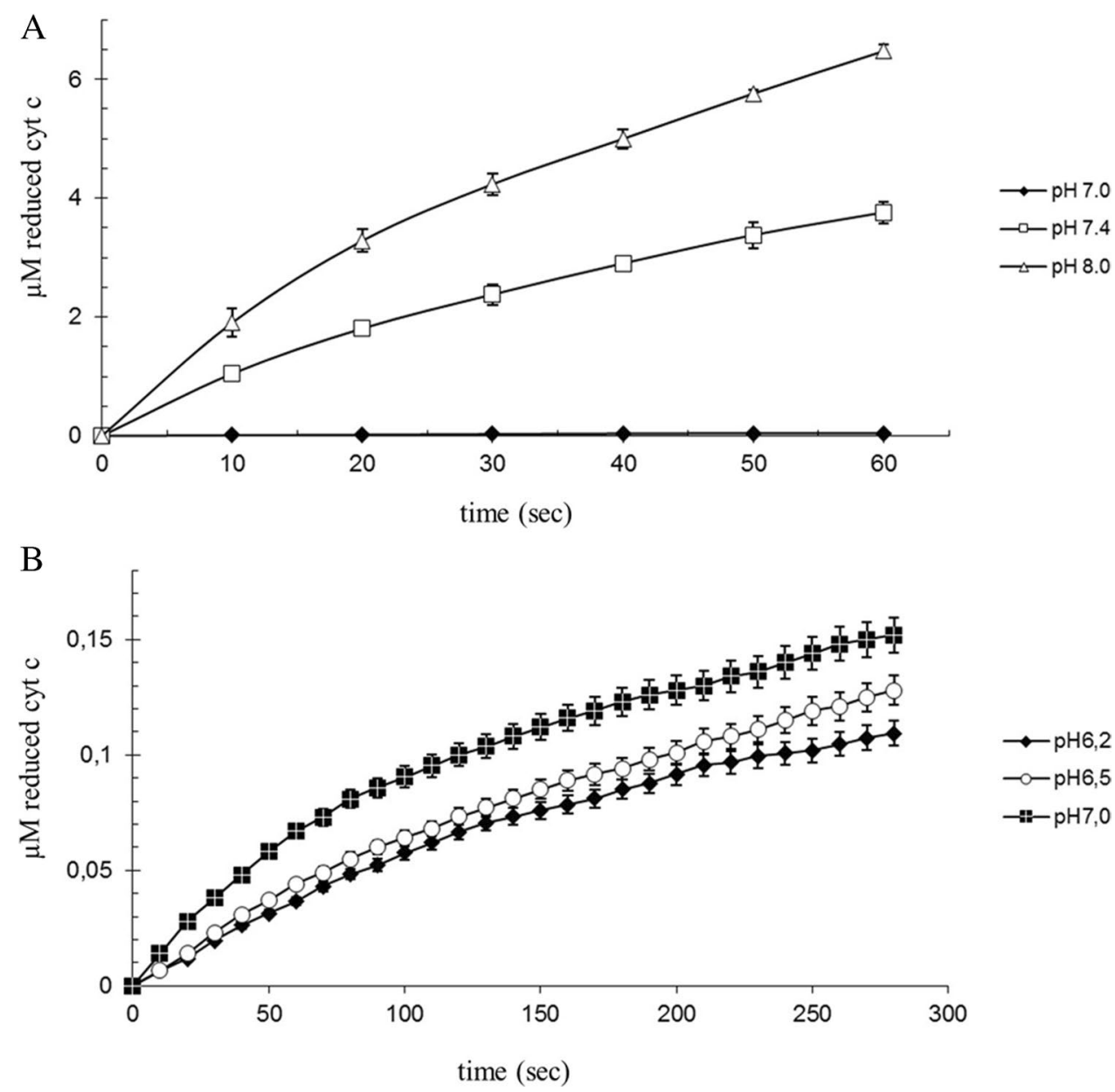


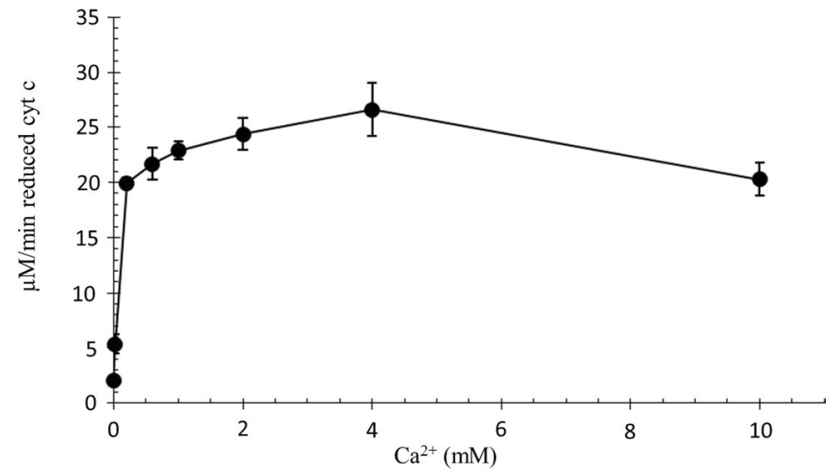

Fig. 2 Cyt $\mathrm{c}$ reduction by GSH at differently concentrations of $\mathrm{Ca}^{2+}$. $100 \mu \mathrm{M}$ bovine cytochrome c, $1 \mathrm{mM} \mathrm{GSH}, \mathrm{Ca}^{2+}$ concentrations $0-10 \mathrm{mM}, 40 \mathrm{mM}$ Tris $/ \mathrm{HCl}(\mathrm{pH}=8.0)$, at $25{ }^{\circ} \mathrm{C}$. The reaction was started by adding cytochrome $\mathrm{c}(\mathrm{n}=6 \pm \mathrm{SD})$

(DTT) can reduce cyt $\mathrm{c}$. At the same thiol concentration $(1 \mathrm{mM})$ rate the cyt $\mathrm{c}$ reduction was at least double that of cysteine than GSH and DTT (pH 7.0 and $\mathrm{pH}$ 8.0;
$\mathrm{T}=25^{\circ} \mathrm{C} ; \mathrm{p}<0.05$ ) (Fig. 4). The ratio of Cys:GSH the cyt $c$ reduction rate was independent from $\mathrm{Ca}^{2+}$.

\section{Model of intermembrane bound cyt c}

\section{Negative phospholipids decrease the cytochrome c reduction of glutathione}

Under physiological conditions, cytochrome $\mathrm{c}$ is not reduced by GSH. The cyt $\mathrm{c}$ is attached to CL with ionic and/or hydrogen and hydrophobic bonds.

The fastest reduction of free cyt $\mathrm{c}$ by GSH was measured at $\mathrm{pH}=8.0$. Anionic phospholipids (phosphatidic acid (PA), phosphatidyl-serine (PS), cardiolipin (CL)) decrease the rate of cytochrome $\mathrm{c}$ reduction. The inhibitor effect is concentration dependent. PS has the poorest inhibitor effect, while CL has the strongest effect (Fig. 5) at a phospholipid concentration of $250 \mu \mathrm{g} / \mathrm{ml}$.
Fig. 3 Cyt c reduction by GSH at differently concentrations of $\mathrm{Mg}^{2+} .100 \mu \mathrm{M}$ bovine cytochrome c, $1 \mathrm{mM}$ GSH, $\mathrm{Mg}^{2+}$ concentrations $0-10 \mathrm{mM}$ $40 \mathrm{mM}$ Tris $/ \mathrm{HCl}(\mathrm{pH}=8.0)$, at $25^{\circ} \mathrm{C}$. The reaction was started by adding cytochrome $\mathrm{c}$ $(\mathrm{n}=6 \pm \mathrm{SD})$
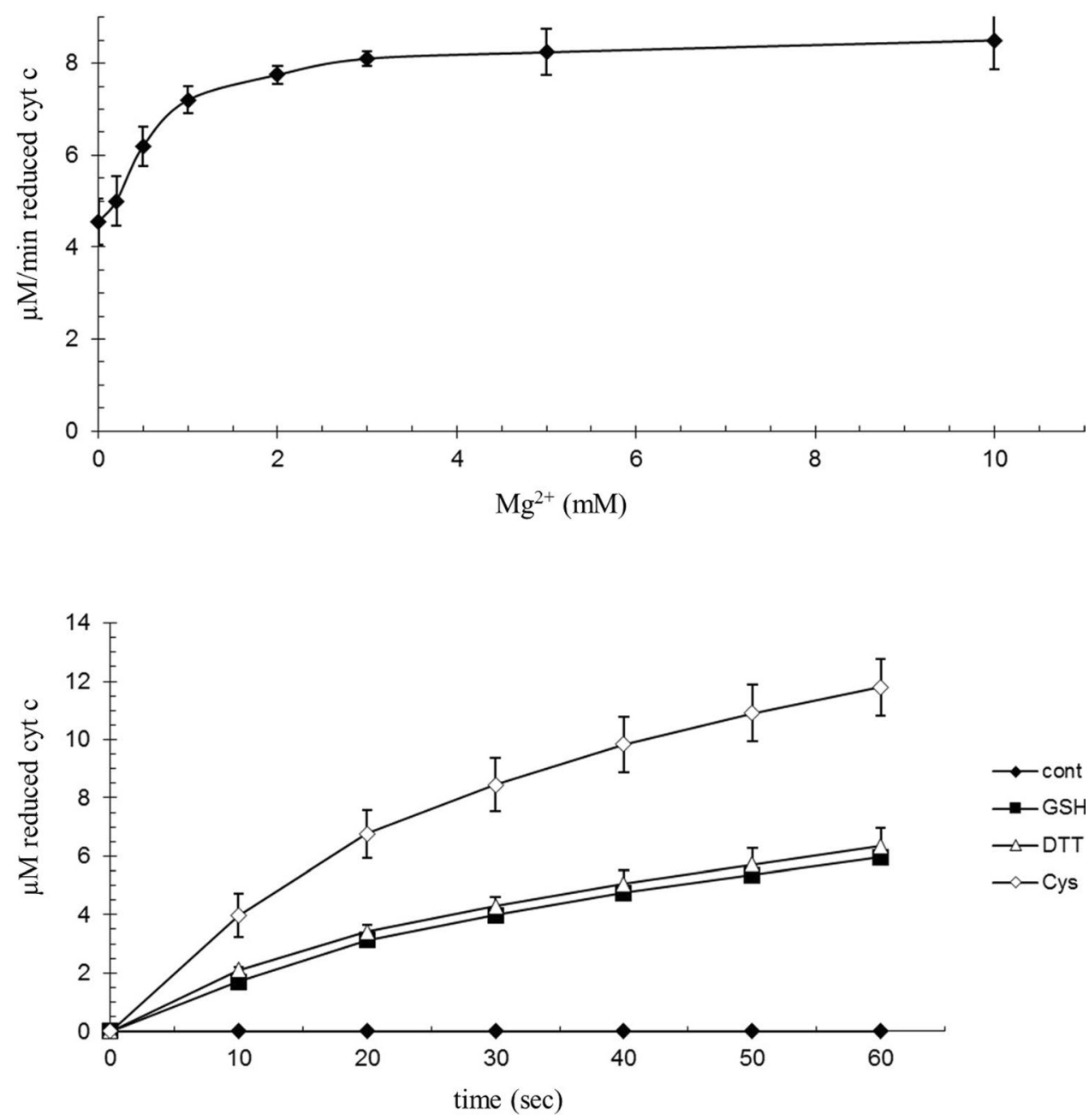
Fig. 5 Effect of phospholipids on the reduction rate of cytochrome c by GSH. $100 \mu \mathrm{M}$ bovine cytochrome c, $40 \mathrm{mM}$ Tris/HCl $(\mathrm{pH}=8.0) ; 0.1 \mathrm{mM}$ EDTA, at $25^{\circ} \mathrm{C} ; 250 \mu \mathrm{g} / \mathrm{ml}$ phosphatidic acid (PA); $250 \mu \mathrm{g} /$ $\mathrm{ml}$ phosphatidyl-serine (PS); $250 \mu \mathrm{g} / \mathrm{ml}$ cardiolipin (CL) $1 \mathrm{mM} \mathrm{GSH} ; 5 \mathrm{v} / \mathrm{v} \%$ ethanol (phospholipid solvent). The reaction was started by adding cytochrome c

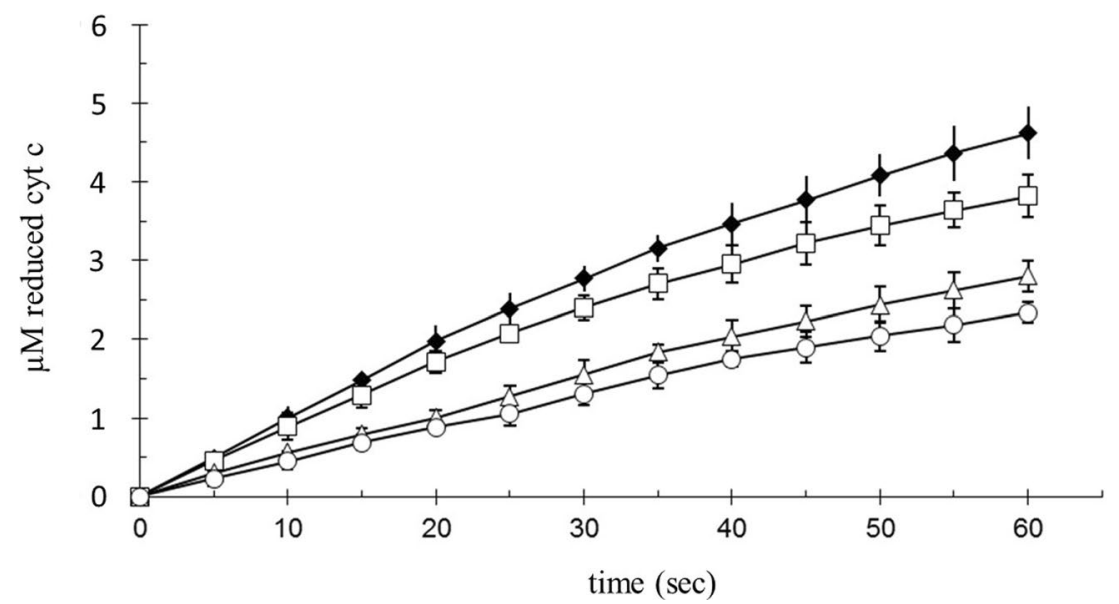

$\rightarrow-P S$

$\rightarrow-P A$

$\multimap-C L$

Fig. 6 Effect of $\mathrm{Ca}^{2+}, \mathrm{Mg}^{2+}$ and phospholipids on the reduction rate of cytochrome $\mathrm{c}$ by GSH. $100 \mu \mathrm{M}$ bovine cytochrome c; $40 \mathrm{mM}$ Tris/ $\mathrm{HCl}(\mathrm{pH}=8.0)$; $5 \mathrm{v} / \mathrm{v} \%$ ethanol (cardiolipin solvent); $1 \mathrm{mM} \mathrm{GSH}$; at $25^{\circ} \mathrm{C}$. $250 \mu \mathrm{g} / \mathrm{ml}$ cardiolipin (CL); $25 \mu \mathrm{g} / \mathrm{ml}$ cardiolipin and $1 \mathrm{mM}$ $\mathrm{Ca}^{2+}(\mathrm{Ca}, \mathrm{CL})$; control (cont) was without cardiolipin, $\mathrm{Ca}^{2+}$, $\mathrm{Mg}^{2+}$. The reaction was started by adding cytochrome $\mathrm{c}$
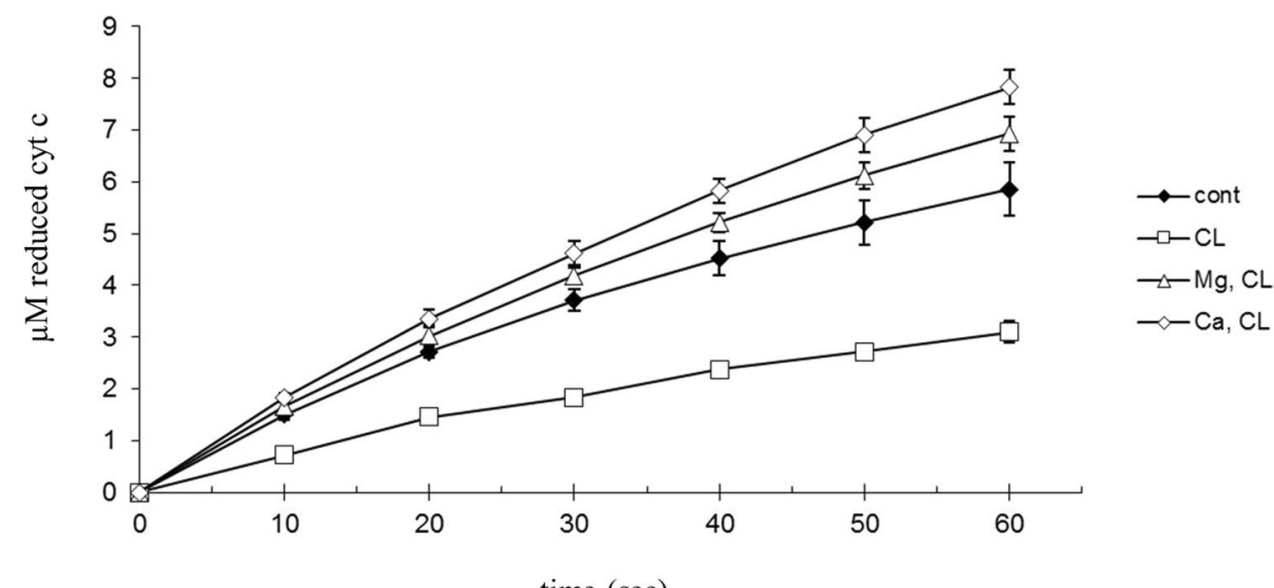

time (sec)

\section{The effect of $\mathrm{Ca}^{2+}, \mathrm{Mg}^{2+}$ and phospholipids on the reduction rate of cytochrome $\mathrm{c}$ by GSH}

Using a concentration of $250 \mu \mathrm{g} / \mathrm{ml}$ anionic phospholipids to model the membrane bound cyt c, $1 \mathrm{mM} \mathrm{Ca}^{2+}$ or $\mathrm{Mg}^{2+}$ increases the reduction rate of cytochrome $\mathrm{c}$ (Fig. 6). The inhibitor effect of anionic phospholipids on the reduction of cytochrome c can be decreased by bivalent cations $\left(\mathrm{Ca}^{2+}\right.$, $\left.\mathrm{Mg}^{2+}\right)$. Isosmotic $\mathrm{NaCl}(1.5 \mathrm{mM})$ did not affect the reduction of cyt c by GSH at $250 \mu \mathrm{g} / \mathrm{ml}$ anionic phospholipids concentration.

\section{GSH as oxygen consumption substrate of mitochondria}

GSH do not change the basic $\mathrm{O}_{2}$ consumption of rat liver mitochondria at $\mathrm{pH} 7.0$ and $1 \mathrm{mM}$ EDTA without added $\mathrm{Mg}^{2+}$ or $\mathrm{Ca}^{2+}$. The $\mathrm{O}_{2}$ consumption of rat liver mitochondria increases at $\mathrm{pH} 8.0 ; 5 \mathrm{mM} \mathrm{GSH}$. $\mathrm{Mg}^{2+}$ increases the oxygen consumption of the mitochondria in a concentrationdependent manner; the maximal effect was measured at a concentration level of $1 \mathrm{mM} \mathrm{Mg}^{2+}$ (Fig. 7). $\mathrm{O}_{2}$ consumption

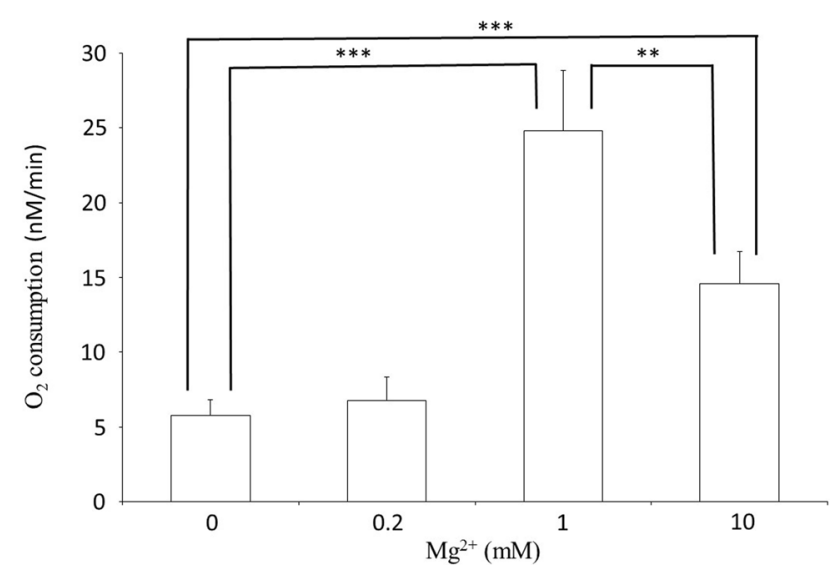

Fig. 7 Effect of $\mathrm{Mg}^{2+}$ on $\mathrm{O}_{2}$ consumption of mitochondria. $80 \mathrm{mM}$ $\mathrm{KCl} ; 20 \mathrm{mM}$ TRIS/HCl; 0,1 mM EGTA; $10 \mathrm{mM} \mathrm{KH} \mathrm{PO}_{4}$; $\mathrm{pH} 8.0$; $37{ }^{\circ} \mathrm{C} ; 5 \mathrm{mM} \mathrm{GSH} ; 1 \mathrm{mg}$ mitochondrial protein $/ \mathrm{ml}$

is observed only in the presence of ADP $(333 \mu \mathrm{M})$. In the absence of ADP, mitochondrial $\mathrm{O}_{2}$ consumption cannot be increased with $\mathrm{Mg}^{2+}$ either. 
$\mathrm{Ca}^{2+}$ has a similar effect as $\mathrm{Mg}^{2+}$. In the presence of $333 \mu \mathrm{M}$ ADP, $1 \mathrm{mM} \mathrm{Ca}^{2+}$ significantly ( $\mathrm{p}^{<0.001)}$ increases $\mathrm{O}_{2}$ consumption, which decreases at a concentration of $10 \mathrm{mM} \mathrm{Ca}^{2+}$ (Fig. 8).

Repeating the measurements without the addition of mitochondria, we found that GSH did not result in $\mathrm{O}_{2}$ consumption.

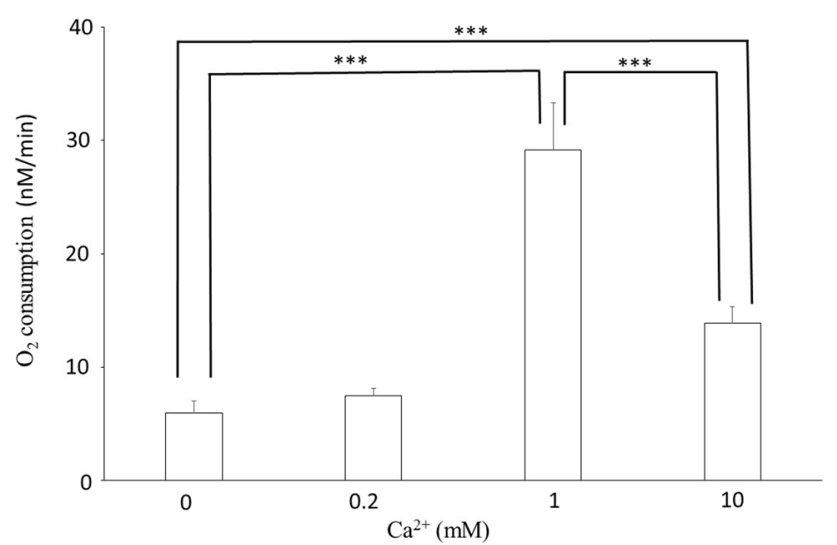

Fig. 8 Effect of $\mathrm{Ca}^{2+}$ on $\mathrm{O}_{2}$ consumption of mitochondria. $80 \mathrm{mM}$

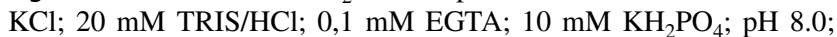
$37^{\circ} \mathrm{C} ; 5 \mathrm{mM} \mathrm{GSH} ; 1 \mathrm{mg}$ mitochondrial protein $/ \mathrm{ml}$

\section{Discussion}

In our work, we mainly characterized the reduction of cytochrome c by GSH by in vitro studies. In the experiments with mitochondria, $\mathrm{O}_{2}$ consumption was measured directly, and dissociation and reduction of cyt $\mathrm{c}$ from the membrane could not be monitored. Our hypothesis in Fig. 9 was based on our in vitro measurements as well as the cyt c pendulum mentioned above.

Our measurements also have methodological implications. The reduction of cyt $\mathrm{c}$ can be based on the measurement of superoxide dismutase activity (determination of superoxide concentration). Preeclamptic placenta can produce reactive oxygen species (Kukor and Valent, 2010). Depending on the physiological concentration of tetrahydrobiopterine (Sahin-Tóth et al. 1997 et al. 1997; Tóth et al. 1997), eNOS monomerizes-dimerizes and can produce NO or superoxide. According to our unpublished results (Kukor, Csomó, Valent), in the presence of DTT, Ca, Mg (1-1 mM) required for eNOS activity (Kukor and Tóth, 1994), the possible superoxide production of the placenta cannot be measured by following cyt $\mathrm{c}$ reduction due to the high background (reduction of cyt c by DTT).

In the presence of phospholipids, but in the absence of $\mathrm{Ca}^{2+}$ and $\mathrm{Mg}^{2+}$, GSH does not reduce cyt $\mathrm{c}$. The cyt $\mathrm{c}$ reduction is most strongly inhibited by mitochondrial CL. There

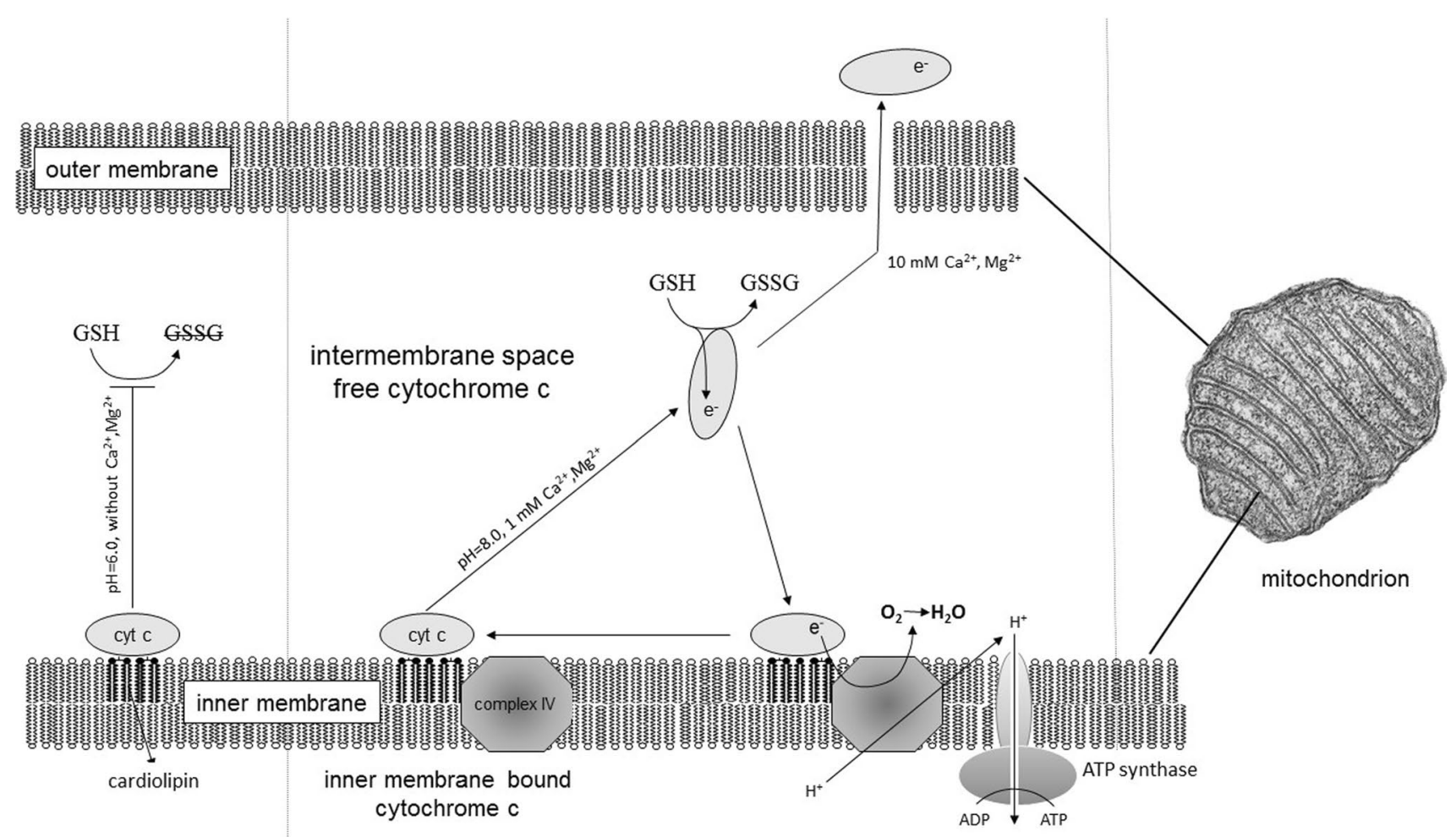

Fig. 9 Summary. Putative mechanism of action. GSH: glutathione; GSSG: oxidized glutathione 
are several reasons for this effect. On one hand, they can promote dissociation of cyt $\mathrm{c}$ from the phospholipids. On the other hand, the divalent cations also increase the reduction of the free (without added phospholipid) cyt $\mathrm{c}$. This suggests that $\mathrm{Ca}^{2+}$ and $\mathrm{Mg}^{2+}$ may directly affect the function of cyt c. Mitochondria uses GSH as a respiratory substrate at high $\mathrm{pH}$, in the presence of $\mathrm{Ca}^{2+}$ or $\mathrm{Mg}^{2+}$, while at $\mathrm{pH} 7.0$, in the presence of EDTA, GSH does not increase the $\mathrm{O}_{2}$ consumption of mitochondria. Cyt $\mathrm{c}$ experiments suggest that GSH may be a substrate for mitochondrial respiration if cyt c dissociates from the inner membrane of the mitochondria.

Without ADP, $\mathrm{Mg}^{2+}$ does not increase mitochondrial $\mathrm{O}_{2}$ consumption. This means that $\mathrm{O}_{2}$ consumption can be linked to a respiratory chain (including cyt c). However, the $\mathrm{Mg}^{2+}$ requirement of $\mathrm{O}_{2}$ consumption, according to our measurements, may result in the cleavage of cyt $\mathrm{c}$ from phospholipids. Cyt $\mathrm{c}$ is present at high concentrations in the intermembrane space of intact mitochondria (up to $0.7 \mathrm{mM}$ ) at physiological intermembrane space ionic strength (Hackenbrock et al. 1986).

Our observation is explained by the fact that cyt $\mathrm{c}$ does not oxidize GSH at low $\mathrm{Mg}^{2+}$ concentrations. At higher ( $1 \mathrm{mM})$ concentrations of $\mathrm{Mg}^{2+}$, cyt $\mathrm{c}$ detaches from the membrane, allowing it to oxidize GSH. Cyt c remains in the intermembrane space, can be attached to the inner membrane, the electron can be transferred to $\mathrm{O}_{2}$. Several articles describe that cytochrome $\mathrm{c}$ can enter the intermembrane space from the inner membrane, be reduced, and then rebound to the inner membrane where it is oxidized by cyt c oxidase. This cycle also has a physiological role, participating in the formation of disulfide bonds in proteins (Endo et al. 2010; Cortese et al. 1998). At higher $\mathrm{Mg}^{2+}$ concentrations $(10 \mathrm{mM})$, cyt $\mathrm{c}$ may be released from the mitochondria and therefore can no longer return to the inner membrane. This reduces mitochondrial $\mathrm{O}_{2}$ consumption (Fig. 9).

The binding of cyt $\mathrm{c}$ to CL causes a change in the redox properties of cyt c (Kagan et al. 2004). The tightly membrane-bound cyt $\mathrm{c}$ has one third of the electron transport capacity of the electrostatically bound cyt $\mathrm{c}$. The CL bound cyt $\mathrm{c}$ would not be able to convert $\mathrm{O}_{2}{ }^{--}$to $\mathrm{O}_{2}$. The anionic lipids-bound cyt $\mathrm{c}$ blocks the electron transfer from a sulphydryl group to cyt $\mathrm{c}$. Therefore, cyt $\mathrm{c}$ cannot oxidize glutathione. This affects energy saving, because the electron from NADH comes in to the electron transfer chain at complex I, while the electron of the -SH group comes in at complex IV. The oxidized glutathione that was reduced by glutathione reductase only works with NADH. Changes in the intracellular milieu of the cells, such as alterations in the redox environment, are important regulators of the progression to apoptosis (Pervaiz and Clement 2002). Depletion of GSH is an early hallmark in the progression of cell death in numerous cell types (Circu and Aw 2008, Circu and Aw 2012). The intrinsic mitochondrial apoptotic pathway can be activated by oxidative stress. Various apoptotic stimuli (e.g. reactive oxygen species) mediate permeabilization of the outer mitochondrial membrane and the release of proapoptotic proteins (cyt c, Apaf-1, endonuclease G). Based on our findings, we suppose that the release of cytochrome $\mathrm{c}$ in to the intermembrane space can rapidly decrease the GSH level in the mitochondrial intermembrane space. Cyt c concentration in the intermembrane space may be comparable to the level of GSH, 0.5-1.0 mM (Bayir et al. 2006). $\mathrm{O}_{2}$ consumption of the mitochondria increases at $1 \mathrm{mM} \mathrm{GSH}, \mathrm{pH}$ 8.0, $1 \mathrm{mM} \mathrm{Mg}^{2+}$, thus reduced cyt $\mathrm{c}$ is reoxigenized by oxygen.

Physiological concentration of magnesium $(1 \mathrm{mM})$ causes apoptosis in cesarian placentae tissue culture and apoptosis was reduced by antioxidant agents such as ascorbic acid and N-acetyl-cystein (Black et al. 2001). Serum magnesium concentrations are decreased in normal pregnancy and elevated in preeclampsia (Sanders et al. 1999). Thus it is worth considering the benefits and necessity of magnesium supplementation.

GSH depletion is a common feature of apoptotic cell death. Although previous studies suggested that GSH depletion was only a byproduct of oxidative stress generated during cell death, recent discoveries suggest that GSH depletion are critical regulators of apoptosis (Circu and Aw 2012). Some reports suggest that mitochondrial GSH depletion is important in triggering the cell death cascade (Circu and Aw 2012, Lash 2006, Brookes et al. 2004). It seems that the oxidation of GSH has an important role in the opening of the PTP in addition to the cyt $\mathrm{c}$ release (Constantini et al. 1996, Beatrice et al. 1984), and the $\mathrm{Mg}^{2+}$ dependent cyt c release (Eskes et al. 1998). Our recent work supposes that free cyt c oxidases GSH, thereby increasing oxidative stress in the mitochondria without reactive oxygen species.

Acknowledgements This work was supported by Scientific Grants of Semmelweis University, Hungary.

Funding Open access funding provided by Semmelweis University.

\section{Declarations}

Disclosure of potential conflicts of interest The authors declare that they have no conflict of interest.

Open Access This article is licensed under a Creative Commons Attribution 4.0 International License, which permits use, sharing, adaptation, distribution and reproduction in any medium or format, as long as you give appropriate credit to the original author(s) and the source, provide a link to the Creative Commons licence, and indicate if changes were made. The images or other third party material in this article are included in the article's Creative Commons licence, unless indicated otherwise in a credit line to the material. If material is not included in the article's Creative Commons licence and your intended use is not permitted by statutory regulation or exceeds the permitted use, you will need to obtain permission directly from the copyright holder. To view a copy of this licence, visit http://creativecommons.org/licenses/by/4.0/. 


\section{References}

Alvarez-Paggi D, Hannibal L, Castro MA, Oviedo-Rouco S, Demicheli V, Tórtora V, Tomasina F, Radi R, Murgida DH (2017) Multifunctional cytochrome c: learning new tricks from an old dog. Chem Rev 117(21):13382-13460

Aon MA, Cortassa S, Maack C, O'Rourke B (2007) Sequential opening of mitochondrial ion channels as a function of glutathione redox thiol status. J Biol Chem 282(30):21889-21900

Bártfai T (1979) Preparation of metal-chelate complexes and the design of steady-state kinetic experiments involving metal nucleotide complexes. Adv Cyclic Nucleotide Res 10:219-242

Bayir H, Fadeel B, Palladino MJ, Witasp E, Kurnikov IV, Tyurina YY, Tyurin VA, Amoscato AA, Jiang J, Kochanek PM, DeKosky ST, Greenberger JS, Shvedova AA, Kagan VE (2006) Apoptotic interactions of cytochrome c: Redox flirting with anionic phospholipids within and outside of mitochondria. Biochem Biophys Acta 1757:648-659

Beatrice MC, Stiers DL, Pfeiffer DR (1984) The role of glutathione in the retention of $\mathrm{Ca}^{2+}$ by liver mitochondria. $\mathrm{J}$ Biol Chem 259(2):1279-1287

Black S, Yu H, Lee J, Sachchithananthan M, Medcalf RL (2001) Physiologic concentrations of magnesium and placental apoptosis: Prevention by antioxidants. Obstet Gynecol 98(2):319-324

Bradford MM (1976) A rapid and sensitive method for the quantitation of microgram quantities of protein utilizing the principle of proteindye binding. Anal Biochem 72:248-254

Brookes PS, Yoon Y, Robotham JL, Anders MW, Sheu SS (2004) Calcium, ATP, and ROS: a mitochondrial love-hate triangle. Am J Physiol Cell Physiol 287:C817-C833

Circu ML, Aw TY (2008) Glutathione and apoptosis. Free Radic Res 42:689-706

Clayton, D.A., and Shadel, G.S. 2014. Isolation of mitochondria from animal tissue. Cold Spring Harb Protoc. 2014(10):pdb.prot080010

Cortese JD, Voglino AL, Hackenbrock CR (1995) Persistence of cytochrome $\mathrm{c}$ binding to membranes at physiological mitochondrial intermembrane space ionic strength. Biochem Biophys Acta 1228:216-228

Cortese JD, Voglino AL, Hackenbrock CR (1998) Multiple conformations of physiological membrane-bound cytochrome c. Biochemistry 37(18):6402-6409

Costantini P, Chernyak BV, Petronilli V, Bernardi P (1996) Modulation of the mitochondrial permeability transition pore by pyridine nucleotides and dithiol oxidation at two separate sites. J Biol Chem 271(12):6746-6751

Endo T, Yamano K, Kawano S (2010) Structural basis for the disulfide relay system in the mitochondrial intermembrane space. Antioxid Redox Signal 13(9):1359-1373

Eskes R, Antonsson B, Osen-Sand A, Montessuit S, Richter C, Sadoul R, Mazzei G, Nichols A, Martinou JC (1998) Bax-induced cytochrome $\mathrm{C}$ release from mitochondria is independent of the permeability transition pore but highly dependent on $\mathrm{Mg} 2+$ ions. J Cell Biol 143(1):217-224

Giacomello M, Drago I, Pizzo P, Pozzan T (2007) Mitochondrial $\mathrm{Ca}(2+)$ as a key regulator of cell life and death. Cell Death Differ 14(7):1267-1274
Gupte SS, Hackenbrock CR (1988) J Biol Chem 263:5248-5253

Hackenbrock CR, Chazotte B, Gupte SS (1986) J Bioenerg Biomemb 18:331-368

Hancock JT, Desikan R, Neill SJ (2001) Does the redox status of cytochrome $C$ act as a fail-safe mechanism in the regulation of programmed cell death? Free Radical Biol Med 31(5):697-703

Kagan VE, Borisenko GG, Tyurina YY, Tyurin VA, Jiang J, Potapovich AI, Kini V, Amoscato AA, Fujii Y (2004) Oxidative lipidomics of apoptosis:redox interactions of cytochrome c with cardiolipin and phosphatidylserine. Free Radical Biol Med 37(12):1963-1985

Kukor Z, Tóth M (1994) Ca(2+)-dependent and $\mathrm{Ca}(2+)$-independent NO-synthesizing activities of human primordial placenta. Acta Physiol Hung 82(4):313-319

Kukor Z, Valent S (2010) Nitric oxide and preeclampsia [A nitrogén-monoxid-szintézis zavarai praeeclampsiában]. Orv Hetil 151(52):2125-2135

Lash LH (2006) Mitochondrial glutathione transport: physiological, pathological and toxicological implications. Chem Biol Interact 163:54-67

Ott M, Robertson JD, Gogvadze V, Zhivotovsky B, Orrenius S (2002) Cytochrome c release from mitochondria proceeds by a two-step process. Proc Natl Acad Sci USA 99:1259-1263

Pastore A, Federici G, Bertini E, Piemonte F (2003) Analysis of glutathione: implication in redox and detoxification. Clin Chim Acta 333:1-39

Pervaiz S, Clement MV (2002) A permissive apoptotic environment: function of a decrease in intracellular superoxide anion and cytosolic acidification. Biochem Biophys Res Commun 290:1145-1150

Ribas V, García-Ruiz C, Fernández-Checa JC (2014) Glutathione and mitochondria. Front Pharmacol 5:151

Sahin-Tóth, M., Kukor, Z., Tóth, M. 1997. Tetrahydrobiopterin preferentially stimulates activity and promotes subunit aggregation of membrane-bound calcium-dependent nitric oxide synthase in human placenta. Molecular Human Reproduction. (4): 293-298.

Sanders R, Konijnenberg A, Huijgen HJ, Wolf H, Boer K, Sanders GT (1999) Intracellular and extracellular, ionized and total magnesium in pre-eclampsia and uncomplicated pregnancy. Clin Chem Lab Med 37(1):55-59

Tóth M, Kukor Z, Sahin-Tóth M (1997) Activation and dimerization of type III nitric oxide synthase by submicromolar concentrations of tetrahydrobiopterin in microsomal preparations from human primordial placenta. Placenta 18(2-3):189-196

Wahlländer A, Soboll S, Sies H, Linke I, Müller M (1979) Hepatic mitochondrial and cytosolic glutathione content and the subcellular distribution of GSH-S-transferases. FEBS Lett 97(1):138-140

Williams NH, Yandell JK (1985) Reduction of oxidized cytochrome c by ascorbate ion. Biochim Biophys Acta 810(2):274-277

Publisher's note Springer Nature remains neutral with regard to jurisdictional claims in published maps and institutional affiliations. 